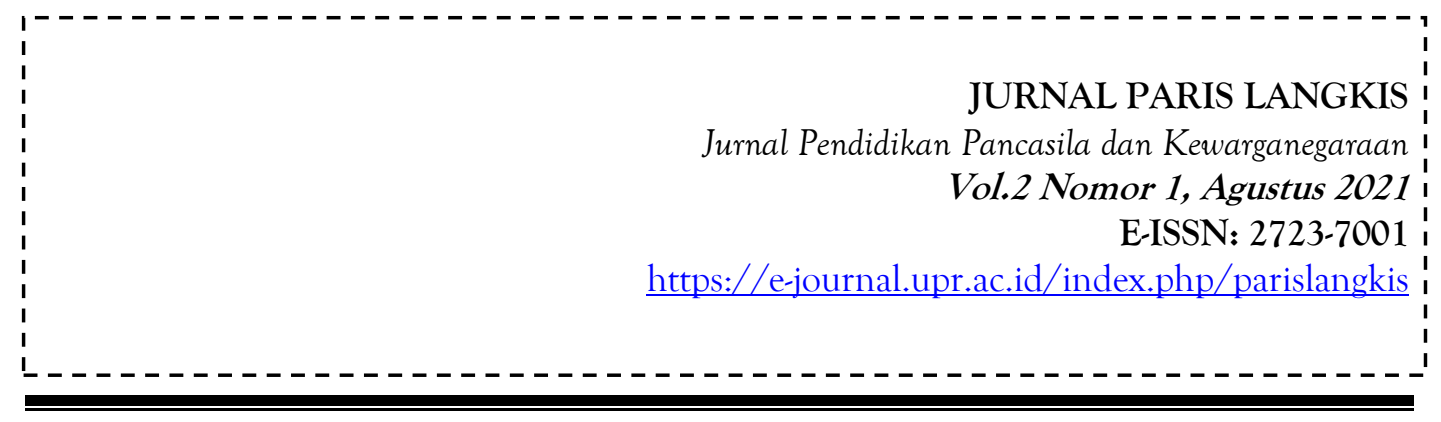

\title{
VARIASI METODE MENGAJAR GURU DALAM MENGATASI KEJENUHAN SISWA DI SEKOLAH MENENGAH PERTAMA
}

\author{
Fatniaton Adawiyah \\ Sekolah Tinggi Ilmu Tarbiyah Al-Azhar Diniyyah (STITAD) JAMBI \\ fatniaton16@gmail.com
}

\begin{abstract}
Abstrak
Penelitian ini bertujuan untuk mengetahui Bagaimana Variasi Metode mengajar Guru dalam mengatasi kejenuhan siswa di Sekolah Menengah Pertama. Apa kendala dalam menciptakan Variasi Metode mengajar Guru untuk mengatasi kejenuhan siswa di Sekolah Menengah Pertama. Apa Upaya yang dilakukan untuk menciptakan Variasi Metode mengajar Guru dalam mengatasi kejenuhan siswa di Sekolah Menengah Pertama. Penelitian ini menggunakan pendekatan kualitatif deskriptif. Dalam memperoleh data peneliti menggunakan metode wawancara, observasi, dan dokumentasi. Analisis data dalam penelitian ini meliputi reduksi data, penyajian data, dan penarikan kesimpulan. Pengecekan keabsahan data menggunakan ketekunan peneliti dan triangulasi sumber data. Tahap-tahap penelitian dalam penelitian ini meliputi tahap pra lapangan, tahap pekerjaan lapangan, tahap analisis data dan tahap penulisan laporan. Hasil penelitian ini penyimpulkan bahwa: 1) guru PAI di Sekolah menggunakan metode ceramah diselingi dengan metode tanya jawab, selain metode-metode tersebut guru kadang-kadang juga memberikan metode diskusi. 2) Faktor penghambat, Kurangnya kemampuan guru dalam mengembangkan dan menerapkan metode pembelajaran yang bervariasi, Kurangnya pengetahuan guru tentang siswa-siswa yang dihadapi seperti tingkat kecerdasan siswa, bakat dan minatnya; Guru kurang matang dalam mempersiapkan seperangkat pembelajarannya sehingga menghambat dalam pelaksanaan pembelajaran; serta kurangnya sarana yang tersedia dalam menunjang pembelajaran. 3) upaya yang dilakukan guru mengkombinasikan beberapa metode pembelajaran misalnya kombinasi penggunaan metode ceramah tanya jawab dan tugas, metode ceramah diskusi dan tugas, metode ceramah demonstrasi dan eksperimen, dan lain sebagainya serta meningkatkan keterampilan mengajar khususnya keterampilan menggunakan metode yang bervariasi dalam pembelajaran yang baik dan terarah.
\end{abstract}

Kata Kunci: Variasi; Metode Mengajar; Kejenuhan Siswa.

\section{Paris Langkis}

Vol.2 Nomor 1, Agustus 2021 


\section{A. PENDAHULUAN}

Pendidikan sebagai wahana untuk mencapai kesejahteraan hidup di dunia. Tanpa pendidikan, kehidupan sosial kemasyarakatan akan mengalami kesulitan, minimal sulitnya berkomunikasi dengan sesamanya. Karena begitu pentingnya pendidikan bagi umat manusia, kualitas pendidikan dimana kualitas pendidikan itu biasanya ditentukan oleh kualitas pembelajarannya. Pendidikan mempunyai peranan yang sentral bagi perkembangan dan perwujudan individu, terutama bagi pembagunan bangsa dan Negara. Yang selaras dengan tujuan pendidikan nasional ialah untuk mencerdaskan kehidupan berbangsa dan bernegara, sekolah sebagai institusi pendidikan formal memiliki tugas membimbing dan melatih, dengan demikian sekolah diharapkan dapat mengembangkan kemampuan peserta didik menuju kedewasaan serta mengembangkan kemampuan individu secara optimal. Pendidikan adalah usaha yang bersifat mendidik, membimbing, membina, mempengaruhi, dan mangarahkan dengan seperangkat ilmu pengetahuan. (Ahmad Beni, 2012)

Dalam Undang-undang Sisdiknas Pendidikan adalah usaha sadar dan terencana untuk mewujudkan suasana belajar dan proses pembelajaran agar peserta didik secara aktif mengembangkan potensi dirinya untuk memiliki kekuatan spiritual keagamaan, pengendalian diri, kepribadian, kecerdasan, ahlak mulia, serta keterampilan yang diperlukan dirinya, masyarakat, bangsa, dan negara. (UU Guru $\&$ Dosen 2005)

Belajar adalah suatu aktivitas atau suatu proses untuk memperoleh pengetahuan, meningkatkan keterampilan, memperbaiki prilaku, sikap dan mengokohkan kepribadian. Sedangkan mengajar adalah menanamkan pengetahuan pada anak. (Sugiono, 2011)

Upaya pemerintah untuk mewujudkan tujuan pendidikan di Indonesia dengan mengadakan pembaharuan sistem pendidikan nasional, di antaranya pembaharuan dan penghapusan diskriminasi antara pendidikan yang dikelola masyarakat, serta perbedaan antara pendidikan keagamaan dan pendidikan umum. Pembaruan sistem pendidikan nasional dilakukan untuk memperbarui visi, misi dan metode pembangunan pendidikan nasional. Pendidikan nasional mempunyai visi terwujudnya sistem pendidikan sebagai pranata sosial yang kuat dan berwibawa untuk memberdayakan semua Warga Negara Indonesia berkembang menjadi manusia yang berkualitas sehingga mampu dan proaktif menjawab tantangan zaman yang selalu berubah.

Memperdalam ilmuan merupakan suatu keharusan, dan tugas seorang guru untuk memberikan pengetahuan dalam proses pembelajaran kepada setiap generasi serta senantiasa meningkatkan keterampilan dan pengetahuannya sebagai seorang guru. sebagaimana Firman Allah SWT, dalam Al-Qur'an surah At-Taubah: 122:

\section{Paris Langkis}

Vol.2 Nomor 1, Agustus 2021 
Artinya: Tidak sepatutnya bagi mukminin itu pergi semuanya (ke medan perang). mengapa tidak pergi dari tiap-tiap golongan di antara mereka beberapa orang untuk memperdalam pengetahuan mereka tentang agama dan untuk memberi peringatan kepada kaumnya apabila mereka telah kembali kepadanya, supaya mereka itu dapat menjaga dirinya. (Q.S. At-Taubah: 122).

Ayat di atas menurut Mahmud Yunus mengungkapkan bahwa setiap orang mukmin harus mampu memberikan perhatian lebih kepada ilmu pengetahuan. Jika kita kaitkan dengan proses pendidikan sekarang, yaitu seorang pendidik tentunya harus selalu meningkatkan keahlian atau keterampilannya sebagai pendidik agar tujuan pendidikan dapat tercapai dengan baik salah satu caranya adalah dengan mengadakan variasi mentode mangajar.

Berdasakan gran tour awal peneliti terlihat bahwa masih ada guru yang belum menggunakan variasi metode dalam mengajar dan hal itu membuat siswasiswa merasa jenuh dengan kegiatan belajar mengajar sehingga materi yang disampaikan guru kepada siswa tidak maksimal dan tidak bisa dimengerti oleh siswa, sehingga banyak siswa yang kurang memahami materi pelajaran. Selain itu metode yang selalu digunakan oleh guru kebanyakan hanya metode ceramah, sehingga siswa menjadi tidak begitu aktif dalam kegiatan belajar mengajar tersebut.

Dari beberapa uraian di atas dapat dilihat bahwa betapa pentingnya dan perlunya kemampuan seorang guru dalam menggunakan metode mengajar agar kejenuhan siswa dalam belajar dapat diatasi sedini mungkin, Berdasarkan hal tersebut peneliti sangat tertarik untuk melakukan penelitian tentang Variasi Metode mengajar Guru dalam mengatasi kejenuhan siswa di Sekolah Menengah Pertama.

1. Bagaimana Variasi Metode Mengajar Guru Dalam Mengatasi Kejenuhan Siswa.?

2. Apa Kendala Guru dalam Mengatasi Kejenuhan Siswa.?

3. Apa Upaya Yang Dilakukan Guru Untuk Mengatasi Kejenuhan Siswa.?

Variasi

Hamid Darmadi menjelaskan bahwa pengertian variasi merujuk pada tindakan dan perbuatan guru yang disengaja ataupun secara spontan yang dimaksudkan untuk mengacu dan mengingat perhatian siswa selama pelajaran berlangsung. (Syamdani, 2013)

Menurut Syaiful Bahri Djamarah dan Aswan Zain keterampilan mengadakan variasi dalam proses mengajar akan meliputi tiga aspek, yaitu variasi dalam gaya mengajar, variasi dalam menggunakan media dan bahan pengajaran, dan variasi dalam interaksi antara guru dan siswa. Dengan demikian apabila ketiga komponen tersebut dikombinasikan dalam penggunaanya atau secara integrasi, maka akan meningkatkan perhatian siswa, membangkitkan keinginan dan kemauan belajar. Penggunaan variasi terutama ditujukan terhadap perhatian siswa, motivasi, dan belajar siswa. (Syaiful Bahri, 2006)

\section{Paris Langkis}

Vol.2 Nomor 1, Agustus 2021 
Tujuan mengadakan variasi dimaksud adalah:

1. Meningkatan dan memelihara perhatian siswa terhadap relevansi proses belajar mengajar. Dalam proses belajar mengajar perhatian siswa terhadap materi pelajaran yang diberikan sangat dituntut. Sedikitpun tidak diharapkan adanya siswa yang tidak atau kurang memperhatikan penjelasan guru, karena hal itu akan menyebabkan siswa tidak mengerti akan bahan yang diberikan guru. Karena itu, guru selalu memperhatikan variasi mengajarnya, apakah sudah dapat menigkatkan dan memelihara perhatian siswa terhadap materi yang dijelaskan atau belum.

2. Memberikan Kesempatan Kemungkinan Berfungsinya Motivasi

Motivasi mempunyai peranan penting dalam belajar. Seorang siswa tidak akan dapat belajar dengan baik dan tekun jika tidak ada motivasi didalam dirinya. Maka dari itu, seorang selalu memperhatikan masalah motivasi ini dan berusaha agar tetap bergejolak di dalam diri setia siswa selama pengajaran berlansung.

3. Membentuk Sikap Positif Terhadap Guru dan Sekolah

Adalah suatu kenyataan yang tidak bisa dipungkiri bahwa di kelas ada siswa tertentu yang kurang senang terhadap seorang guru. gur tersebut sedang memberikan materi pelajaran kelas. Kurang senangnya seorang siswa terhadapa guru bisa jadi disebabkan gaya mengajar guru yang kurang bervariasi (Berkat et al. 2021). Metode mengajar yang digunakan itu-itu saja. Misalnya, hanya mengunakan metode ceramah untuk setiap kali melaksanakan tugas mengajar dikelas. Tidak pernah terlihat mengunakan metode yang lain. Misalnya metode diskusi, resitasi, tanya jawab, problem solving atau cerita.

4. Memberikan kemungkinan pilihan dan fasilitas belajar individual.

Sebagai seorang guru dituntut untuk mempunyai berbagai keterampilan yang mendukung tugasnya dalam mengajar. Salah satunya adalah Fasilitas belajar yang merupakan kelengkapan belajar yang harus ada di sekolah, fungsinya berguna sebagai alat bantu pengajaran, lengkap tidaknya fasilitas belajar mempengaruhi pemilihan yang harus guru lakukan.

5. Mendorong anak didik untuk belajar

Menyediakan lingkungan belajar adalah tugas guru. Kewajiban belajar adalah tugas anak didik. Belajar memerlukan motivasi sebagai pendorong bagi anak didik adalah motivasi intrinsik yang lahir dari kesadaran akan pentingnya ilmu pengetahuan.

Selain tujuan variasi metode mengajar yang telah disebutkan di atas, seorang guru juga bisa memilih bermacam metode yang digunakan di dalam proses belajar mengajar, sehingga proses pembelajaran dapat berjalan dengan baik dan menyenagkan sebagaimana yang diharapkan oleh peserta didik. Bila guru dalam proses belajar mengajar tidak menggunakan variasi, maka akan membosankan

\section{Paris Langkis}

Vol.2 Nomor 1, Agustus 2021 
siswa, perhatian siswa berkurang, mengantuk dan akibatnya tujuan belajar tidak akan tercapai.

\section{B. PEMBAHASAN}

\section{Metode Mengajar}

Metode mengajar adalah kata yang digunakan untuk menandai serangkaian kegiatan yang diarahkan oleh guru yang hasilnya adalah belajar pada siswa. Metode adalah cara yang digunakan untuk melaksanakan strategi. Metode adalah salah satu alat untuk mencapai tujuan. Dengan memanfaatkan metode secara akurat, guru akan mampu mencapai tujuan pengajaran. Ketika tujuan dirumuskan agar anak didik memiliki keterampilan tertentu, maka metode yang digunakan harus sesuai dengan tujuan pembelajaran. (Syaiful Bahri, 2006)

Kegiatan pembelajaran adalah sebuah interaksi yang bernilai pendidikan, di dalamnya terjadi interaksi edukatif antara guru dan anak didik ketika guru menyampaikan bahan pelajaran kepada anak didik dikelas (Saefulloh 2018). Bahan pelajaran yang guru berikan akan kurang memberikan motivasi kepada anak didik apabila penyampaiannya dengan menggunakan strategi yang kurang tepat. Di sinilah kehadiran metode menempati posisi penting dalam penyampaian bahan pelajaran.

Metode mengajar adalah suatu cara atau jalan yang harus dilalui dalam mengajar, sedangkan mengajar adalah menyajikan bahan pelajaran oleh seseorang kepada orang lain agar orang lain tersebut menguasai dan mengembangkannya. Variasi Metode Mengajar yang digunakan oleh guru sangat mempengaruhi terhdap minat dan motivasi siswa di dalam proses belajar dan pemebelajaran itu sendiri. Variasi Metode yang digunakan oleh guru menimbulkan perbedaan yang berarti bagi proses belajar. Akhirnya, dapat dipahami bahwa penggunaan metode yang tepat dan bervariasi akan dapat dijadikan sebagai alat motivasi ektrisnsik dalam kegiatan belajar mengajar di sekolah. (Mulyani, 2010)

\section{a. Metode dalam Proses Belajar Mengajar}

Kegiatan belajar mengajar dalam melahirkan interaksi unsur-unsur manusiawi adalah sebagai suatu proses dalam rangka mencapai tujuan pengajaran. Belajar adalah perubahan prilaku sebagai akibat dari pengalaman. (Mulyani, 2010)

Tidak ada kata terlambat untuk belajar, karena semua orang dilahirkan sama-sama tidak berilmu, yang akan membedakan seseorang dengan orang lain adalah ilmu yang dimilikinya. (Zainudin, 2010) Salah satu usaha yang tidak pernah guru tinggalkan adalah, bagaimana memahami kedudukan metode sebagai salah satu komponen yang ikut ambil bagian bagi keberhasilan kegiatan belajar mengajar. Macam-macam Metode Mengajar Menurut Syaiful Bahri

\section{Paris Langkis}

Vol.2 Nomor 1, Agustus 2021 
Djamarah dan Aswan Zain ada beberapa macam bentuk metode mengajar yang bisa digunakan oleh guru, yaitu:

1) Metode Proyek

Metode proyek adalah cara penyajian pelajaran yang bertitik tolak dari suatu masalah, kemudian dibahas dari berbagai segi yang berhubungan sehingga pemecahannya secara keseluruhan dan bermakna. Penggunaan metode ini bertolak dari anggapan bahwa pemecahan masalah tidak akan tuntas jika tidak ditinjau dari berbagai segi.

2) Metode Eksperimen

Metode eksperimen adalah cara penyajian pelajaran, di mana siswa melakuakan percobaan dengan mengalami dan membuktikan sendiri sesuatu yang dipelajari.

3) Metode Tugas dan Resitasi

Metode resitasi (penuganasan) adalah metode penyajian bahan di mana guru memberikan tugas tertentu agar siswa melakukan kegiatan belajar.

4) Metode Diskusi

Metode diskusi adalah cara penyajian pelajaran, di mana siswa dihadapkan kepada suatu masalah yang bisa berupa pernyataan atau pertanyaan yang bersifat problematis untuk dibahas dan dipecahkan bersama.

5) Metode Demonstrasi

Metode demonstrasi adalah cara penyajian pelajaran dengan meragakan atau mempertunjukkan kepada siswa suatu proses, situasi, atau benda tertentu yang sedang dipeljari, baik sebenarnya ataupun tiruan yang sering disertai dengan penjelasan lisan.

6) Metode Problem Solving

Metode Problem Solving (pemecahan masalah) bukan hanya sekedar metode mengajar, tetapi juga merupakan suatu metode berpikir, sebab dalam problem solving dapat menggunakan metode-metode lainnya yang dimulai denga mencari data sampai kepada mmenarik kesimpulan.

7) Metode Karya Wisata

Terkadang dalam proses belajar mengajar siswa perlu diajak ke luar sekolah, untuk meninjau tempat tertentu atau objek yang lain. Hal ini bukan sekedar rekreasi, tetapi untuk belajar atau memperdalam pelajaran dengan melihat kenyataannya.

8) Metode Tanya Jawab

Metode Tanya jawab adalah cara penyajian pelajaran dalam bentuk pertanyaan yang harus dijawab, terutama dari guru kepada siswa, tetapi dapat pula dari siswa kepada guru.

9) Metode Latihan

\section{Paris Langkis}

Vol.2 Nomor 1, Agustus 2021 
Metode latihan atau metode training, merupkan suatu cara mengajar yang baik untuk menanamkan kebiasaan-kebiasaan tertentu. Juga sebagai sarana untuk memelihara kebiasaan yang baik.

10) Metode Ceramah

Metode ceramah adalah metode yang boleh dikatakan metode tradisional, karena sejak dulu metode ini telah dipergunakan sebagai alat komunikasi lisan antara guru dengan anak didik dalam proses belajar mengajar. (Oemar Hamalik, 2012) Meski metode ini lebih banyak menuntut keaktifan guru dari pada anak didik, tetapi metode ini tidak dapat ditinggalkan begitu saja dalam kegiatan pengajaran. Apalagi dalam pendidikan dan pengajaran tradisional seperti di pedesaan yang kekurangan fasilitas. (Oemar Hamalik, 20120)

\section{Guru}

Profesi guru adalah sebuah pekerjaan yang sangat mulia, tugas guru ialah mentransfer ilmu pengetahuan, pengalaman, penanaman nilai-nilai budaya, moral dan agama. Selain itu guru juga berpungsi sebagai motivator, konsoling dan pemimpin dalam kelas. Kehadiran guru ditengah-tengah masyarakat merupakan unsur utama dan terpenting. Bisa dibayangkan jika ditengah-tengah kehidupan manusia tidak ada seorang guru, kita akan hidup dalam lingkaran tradisi-tradisi kuno serta peradaban kuno, sangat mustahil sebuah bangsa bisa maju tanpa pendidikan dan guru. (Muzayyin, 2011)

Dalam undang-undang Republik Indonesia Nomor 14 Tahun 2005 tentang Guru dan Dosen dinyatakan bahwa "Guru adalah pendidik professional dengan tugas utama mendidik, mengajar, membimbing, mengarahkan, melatih, menilai dan mengevaluasi peserta didik pada pendidikan anak usia dini jalur pendidikan formal, pendidikan dasar dan pendidikan menengah”.

Salah satu factor yang paling menentukan keberhasilan proses belajar mengajar dalam kelas adalah guru, karena itu guru tidak saja mendidik melainkan juga berfungsi sebagai orang dewasa yang bertugas professional memindahkan ilmu pengetahuan yang dikuasai kepada anak didik. (Muzayyin, 2011)

Dalam Undang-undang guru dan dosen dalam pasal 20 guru bekewajiban Merencanakan pembelajaran, melaksanakan proses pembelajaran yang bermutu, serta menilai dan mengevaluasi hasil pembelajaran. Tiga pilar yang menunjukan bahwa guru telah bekerja secara professional dalam melaksanakan tugas kependidikan adalah menguasai materi pelajaran, professional untuk menyampaikan materi pelajaran, serta berkepribadian matang. (UU Guru \& Dosen 2005)

Dari hal tersebut indicator nya adalah bahwa tanggung jawab guru sangat besar terhadap anak didiknya, berhasil atau tidaknya suatu pendidikan tergantung dari kinerja seorang guru.kurangnya tanggung jawab seorang guru bisa

\section{Paris Langkis}

Vol.2 Nomor 1, Agustus 2021 
mengakibatkan rendahnya akhlak siswa serta tidak efektif nya proses belaja mengajar. Di dalam pendidikan, guru merupakan suatu tenaga yang memberikan sumbangan pemikiran yang menumbuh kembangkan pola pemikiran peserta didik. Guru harus memiliki kemampuan dan keterampilan mengajar yang memadai dalam suatu bidang mata pelajaran sebagai seorang pendidik.

\section{Kejenuhan Siswa}

Banyak persoalan mendasar yang dihadapi siswa salah satunya kejenuhan siswa saat proses pembelajaran berlangsung, yang biasanya terjadi karena proses pembelajaran yang membosankan. Siswa merupakan sumber daya utama dan terpenting dalam proses pendidiikan formal. Siswa yang juga biasa disebut dengan anak didik merupakan subjek utama dalam pendidikan. Siswa adalah subyek belajar atau disebut pembelajaran. Kegiatan belajar mengajar dalam melahirkan interaksi unsur-unsur manusiawi adalah sebagai suatu proses dalam rangka mencapai tujuan pengajaran. (Syaiful Bahri, 2006)

Siswa atau peserta didik merupakan salah satu komponen manusiawi yang menempati posisi sentral. Peserta didik diartikan sebagai individu yang sedang berada dalam proses pertumbuhan dan pekembangan baik fisik maupun psikis menurut fitrahnya masing-masing. (Desmita, 2014)

Siswa merupakan individual yang unik, tidak ada dua siswa yang sama persis, tiap siswa memiliki perbedaan dengan satu dengan yang lain. Perbedaan tersebut terdapat pada karakter psikis, kepribadian, sifat-sifatnya, begitu pula minat yang dimiliki dalam mengikuti proses pembelajaran. Siswa adalah penentu terjadi atau tidaknya proses belajar, proses belajar terjadi karena siswa memperoleh sesuatu yang ada dilingkungan sekitar.

Pembelajaran atau belajar yang dilakukan oleh siswa adalah merupakan tindakan yang kompleks. Sebagai tindakan, maka belajar dialami oleh siswa sendiri. Siswa adalah penentu terjadi atau tidaknya proses pembelajaran. Siswa yang juga biasa disebut dengan anak didik merupakan subjek utama dalam pendidikan. Dialah yang belajar setiap saat. Siswa merupakan individual yang unik, tidak ada dua siswa yang sama persis, tiap siswa memiliki perbedaan dengan satu dengan yang lain. Perbedaan tersebut terdapat pada karakter psikis, kepribadian, sifat-sifatnya, begitu pula minat yang dimiliki dalam mengikuti proses pembelajaran

Dari defenisi di atas, maka kejenuhan siswa dapat diartikan sebagai perasaan bosan akibat aktivitas yang berulang- ulang tanpa ada semacam variasi metode mengajar yang dilakukan oleh guru untuk menciptakan kondisi belajar yang menyenangkan dan tidak membosankan bagi siswa.

\section{Metode Penelitian}

Penelitian ini menggunakan pendekatan kualitatif, pendekatan kualitatif adalah prosedur penelitian yang menghasilkan data-data secara deskriptif berupa kata-kata tertulis atau lisan dari manusia dan prilakunya yang dapat diamati

\section{Paris Langkis}

Vol.2 Nomor 1, Agustus 2021 
sehingga tujuan dari penelitian ini adalah pemahaman individu tertentu dan latar belakangnya secara utuh. (Setyadi, 2006)

Penelitian ini merupakan sebuah studi lapangan yang mengungkapkan, menemukan dan menggali informasi tentang Variasi Metode mengajar Guru dalam mengatasi kejenuhan siswa di Sekolah Menengah Pertama yang bersifat deskriptif yaitu menggambarkan apa adanya yang sesuai dengan kenyataan faktual yang ditemukan dilapangan dan jenis penelitian ini adalah penelitian kualitatif. Jadi penelitian kualitatif adalah prosedur penelitian yang menghasilkan data deskriptif berupa kata-kata tertulis atau lisan dari orang-orang dan prilaku yang diamati (Juliansyah Noor, 2011)

Penelitian yang bermaksud untuk memahami fenomena tentang apa yang dialami oleh subjek penelitian misalnya prilaku, tingkah laku anak, dan lain-lain dengan cara deskriptif dalam bentuk kata-kata dan bahawa, pada suatu konteks khusus yang alamiah. Penelitian ini digunakan untuk mendeskripsikan tentang segala sesuatu yang berkaitan dengan Variasi Metode mengajar Guru dalam mengatasi kejenuhan siswa di Sekolah Menengah Pertama

Dengan pengumpulan data menggunakan teknik observasi, wawancara, studi dokumentasi dan triangulasi. Peneliti melakukan analisis data sejak melaksanakan prapenelitian, saat pengumpulan data sampai dengan akhir tahap penelitian. Miles dan Huberman mengemukakan bahwa aktivitas dalam analisis data kualitatif dilakukan secara interaktif dan berlangsung secara terus menerus sampai selesai, sehingga datanya sudah jenuh. Aktivitas dalam analisis data yaitu reduksi data, penyajian data, dan penarikan kesimpulan. (Sugiono, 2011)

\section{HASIL PENELITIAN DAN PEMBAHASAN}

\section{Variasi Metode Mengajar Guru Dalam Mengatasi Kejenuhan Siswa Di Sekolah Menengah Pertama}

Dalam proses kegiatan belajar mengajar di sekolah, tidak dapat dipungkiri bahwa adakalanya siswa, mengalami kejenuhan. Kejenuhan siswa dalam memperoleh pelajaran dapat diamati selama proses belajar mengajar berlangsung seperti kurang perhatian, mengantuk, mengobrol dengan sesama teman hanya untuk menghindari kejenuhan. Hal ini tentu menjadi problem bagi tercapainya tujuan pembelajaran. Untuk mengatasi kejenuhan itu perlu diciptakan situasi dan kondisi belajar mengajar yang bervariasi. Karena salah satu faktor yang menjadi penyebab kejenuhan siswa adalah guru memakai metode yang kurang bervariasi, sehingga siswa menjadi jenuh.

Dari hasil penelitian didapatkan hasil bahwa dalam menerapkan metode mengajar yang bervariasi, guru PAI di Sekolah Menengah Pertama melakukannya dengan memberikan metode ceramah untuk menyampaikan materi dengan penjelasan yang lebih detail dan luas. Untuk menghindari kebosanan siswa karena

\section{Paris Langkis}

Vol.2 Nomor 1, Agustus 2021 
hanya mendengarkan maka, diselingi dengan metode tanya jawab. Metode tanya jawab ini dilakukan untuk mengetahui kemampuan siswa dalam menerima pelajaran yang telah diberikan.

Selain metode-metode tersebut guru kadang-kadang juga memberikan metode diskusi dalam pembelajarannya dengan tujuan memberi kebebasan pada siswa untuk berpendapat, bertanya dan berfikir dalam suatu permasalahan sehingga dapat memecahkan persoalan tersebut secara bersama-sama.

Di sekolah ini memang cukup banyak metode yang diterapkan dalam proses belajar mengajar, salah satunya metode diskusi yang sering digunakan tenaga pendidik dalam menyampaikan materi pembelajarannya dan saya fikir ini sangat efektif mengingat peran siswa cukup banyak seperti halnya tanya jawab yang secara langsung kemampuan seorang siswa dapat terlihat secara jelas ketika mereka mempertahankan pendapat, dan banyak hal lain yang dapat dikembangkan melalui metode diskusi ini salah satunya membangun kepercayaan diri siswa dalam menyampaikan pendapat atau dalam menjawab pertanyaan.

Dalam memilih suatu metode yang akan dipergunakan guru perlu mempunyai alasan yang kuat dan faktor-faktor yang mendukung pemilihan metode tersebut, seperti karakteristik tujuan kegiatan dan karakteristik siswa yang diajar. Metode mengajar berfungsi sebagai jembatan atau cara guru untuk menyampaikan materi pembelajaran. Pembelajaran tidak akan efektif bila guru terlalu monoton dalam pemilihan metode.

Guru-guru umumnya menggunakan metode pembelajaran ceramah, tanya jawab dan diskusi kelompok, karena memang metode ini yang cukup efektif digunakan untuk siswa Sekolah Menengah Pertama jadi guru-guru disekolah ini hanya Sebagian kecil saja yang meggunakan metode unjuk kerja.

\section{Kendala Dalam Menciptakan Variasi Metode Mengajar Guru Untuk Mengatasi Kejenuhan Siswa Di Sekolah}

Dari hasil observasi dan wawancara peneliti di lapangan didapat hasil bahwa dalam upaya menciptakan variasi metode mengajar untuk mengatasi kejenuhan siswa, ada beberapa kendala yang dihadapi guru.

Kendala dalam mengajar yaitu penggunaan metode mengajar bervariasi, karena tidak ada pelatihan bagi guru-guru dalam menggunakan metode mengajar sehingga banyak guru yang tidak paham dan tidak mengerti dengan penggunaan media, dan ini yang menyebabkan guru tidak menggunakan metode pembelajaran yang bervariasi.

Tidak ada alasan untuk tidak memahami cara mengajar dengan berbagai metode yang bervariasi. Hal ini dikarenakan informasi di era sekarang sangatlah murah. Sudah banyak buku yang menulis tentang cara mengajar dengan metode yang menyenangkan. Selain itu, internet juga dapat diakses 24 jam untuk

\section{Paris Langkis}

Vol.2 Nomor 1, Agustus 2021 
mendapatkan informasi serupa. Kesungguhan guru untuk menyiapkan pembelajaran yang inovatif dan menyenangkan harus ditingkatkan.

Kendala yang dihadapi selama ini sebagai guru biasanya terjadi adalah kemampuan siswa yang tidak sama, siswa yang rajin dan pandai akan mudah diajari sedangkan yang kurang pandai terkadang perlu metode khusus.

Kurangnya pengetahuan guru tentang siswa-siswa yang dihadapi seperti tingkat kecerdasan siswa, bakat dan minat secara tidak langsung mempengaruhi penggunaan variasi metode mengajar guru, karena guru akan kesulitan untuk mempertimbangkan metode yang mana yang sesuai untuk kelompok siswa tertentu. Maka, persiapan terhadap siswa yang akan dihadapi juga penting untuk mengetahui kemampuan siswa sehingga mempermudah guru dalam menentukan metode mengajar di kelas.

Kendala lainnya adalah kebiasaan guru untuk tidak menyiapkan perencanaan pembelajaran (RPP) yang di dalamnya juga mencakup pemilihan metode mengajar, dan pemilihan media untuk menyampaikan materi dalam proses pembelajaran sehingga menghambat dalam pelaksanaan pembelajaran.

Dari hasil pengamatan yang dilakukan peneliti, di Sekolah yang ada masih sedikit bapak/ibu guru yang mengumpulkan Rancangan Pembelajarannya di bagian Kurikulum pada setiap semesternya. Sehingga dari sekian mata pelajaran yang ada, kalaupun ada yang mengumpulkan Rancangan Pembelajaran itupun hanya beberapa orang guru saja yang membuat Rancangan Pembelajaran dan diserahkan dibagian kurikulum. Padahal sebenarnya pemnyusunan rancangan pembelajaran merupakan tugas pokok dari guru sebelum dia melakukan kegiatan pembelajaran.

Melakukan perencanaan pembelajaran adalah merupakan sebuah tugas yang harus dijalankan guru sebelum proses pembelajaran dilaksanakan dengan harapan langkah-langkah dalam pelaksanaan pembelajaran dapat dilaksanakan dengan baik. Dalam setiap mata pelajaran, perencanaan harus selalu dibuat oleh guru dalam arti lain suatu rencana pembelajaran yang harus dikuasai guru sebelum perencanaan dimulai atau dilaksanakan.

Permasalahan lainnya yang menghambat guru untuk menciptakan pembelajaran yang bervariasi adalah sarana dan prasarana yangg kurang memadai. Agar pembelajaran lebih bervariasi maka harus dilengkapi dengan sarana dan prasarana yang menunjang dan juga bervariasi misalnya media pembelajaran. Ketersediaan fasilitas yang menunjang pelaksanaan pembelajaran juga sangat diperlukan agar meode yng digunakan dapat dijalankan dengan baik. Kurangnya media yang tersedia dalam menunjang pembelajaran, seperti tidak ada kaset, VCD, dan alat peraga yang membantu dalam pembelajaran seringkali menjadi alasan guru-guru untuk tidak menggunakan media pada kegiatan belajar mengajar.

\section{Paris Langkis}

Vol.2 Nomor 1, Agustus 2021 
Untuk penggunaan media pebelajaran disini masih relatif sederhana dan jumlahnya yang ada juga tidak memadahi untuk memenuhi seluruh siswa, terkadang susah mau demonstrasi, alat-alat peraga disini masih kurang.

Terbatasnya dana dalam mencukupi sarana prasarana yang memadai di sekolah mengakibatkan tidak tersedianya media-media yang dibutuhkan dalam kegiatan belajar mengajar. Akan tetapi, Seorang guru jangan hanya mengandalkan fasilitas yang ada di sekolah, guru harus dapat mengusahakan sendiri bahan dan media yang akan digunakan sehingga membantu proses mengajarnya.

3. Upaya Yang Dilakukan Guru Untuk Mengatasi Kejenuhan Siswa Di Sekolah

Berdasarkan uraian sebelumnya telah diketahui bahwa terdapat beberapa kendala yang dihadapi guru dalam memvariasikan metode mengajar di Sekolah, yaitu Kurangnya kemampuan guru dalam mengembangkan dan menerapkan metode pembelajaran yang bervariasi, Kurangnya pengetahuan guru tentang siswasiswa yang dihadapi seperti tingkat kecerdasan siswa, bakat dan minatnya; Guru kurang matang dalam mempersiapkan seperangkat pembelajarannya sehingga menghambat dalam pelaksanaan pembelajaran; serta kurangnya sarana yang tersedia dalam menunjang pembelajaran.

Peranan guru meliputi banyak hal, yaitu guru dapat berperan sebagai pengajar, pemimpin kelas, pembimbing, pengatur lingkungan belajar, perencana pembelajaran, supervisor, motivator dan sebagai evaluator. Begitu pentingnya pendidikan bagi setiap manusia, karena tanpa adanya pendidikan sangat mustahil suatu komunitas manusia dapat hidup berkembang sejalan dengan cita-citanya untuk maju, mengalami perubahan, sejahtera dan bahagia sebagaimana pandangan hidup mereka. Semakin tinggi cita-cita manusia semakin menuntut peningkatan mutu pendidikan sebagai sarana pencapaiannya.

Dalam proses pembelajaran kami pihak guru biasanya selalu menggunakan metode-metode yg biasa, misalnya menggunakan metode ceramah, namun tergantung dari materi yang di ajarkan, apabila memungkinkan untuk metode diskusi maka akan menggunakan metode diskusi. Khusus untuk materi lagu kebangsaan, akan di pergunakan metode praktek.

Sebelum memulai proses pembelajaran biasanya selalu memberikan pengarahan terhadap siswa, agar siswa menjadi termotivasi untuk belajar, kemudian di lanjutkan dengan menjelaskan materi pelajaran, kemudian di akhir pelajaran siswa dapat mengerjakan latihan atau mengisi pertanyaan yang telah di berikan, dengan demikian pandangan seorang siswa terhadap metode mengajar guru akan berlangsung baik karena proses yang dilalui dalam sistem pembelajaran sesuai.

Sebagai seorang guru dituntut untuk mempunyai berbagai keterampilan yang mendukung tugasnya dalam mengajar. Penguasaan metode mengajar yang dituntut kepada guru tidak hanya satu atau dua metode, tetapi lebih banyak dari itu. penguasaan metode mengajar dalam jumlah yang banyak lebih memungkinkan

\section{Paris Langkis}

Vol.2 Nomor 1, Agustus 2021 
guru untuk melakukan pemilihan metode mana yang dipakai dalam rangka menunjang tugasnya mengajar dikelas.

Selanjutnya, upaya yang dapat dilakukan guru dalam membuat variasi metode mengajar untuk menyajikan materi pelajaran kepada siswa, adalah dengan mengkombinasikan beberapa metode pembelajaran misalnya kombinasi penggunaan metode ceramah tanya jawab dan tugas, metode ceramah diskusi dan tugas, metode ceramah demonstrasi dan eksperimen, dan lain sebagainya.

Sebenarnya metode pembelajaran digunakan untuk mempermudah kegiatan menyampaikan materi pembelajaran oleh guru kepada siswa, sehingga siswa mudah memahami materi yang disampaikan oleh guru serta mampu mencapai tujuan pembelajaran. beberapa Pelajaran pada dasarnya bersifat mengahafal dan mempraktekkan, maka metode tersebutlah yang sering kita gunakan.

Untuk meningkatkan keterampilan mengajar khususnya keterampilan menggunakan metode yang bervariasi dalam pembelajaran yang baik dan terarah maka perlu adanya usaha-usaha yang harus ditempuh supaya mutu pengajaran menjadi lebih baik. Ada beberapa upaya atau usaha yang menurut penulis kiranya dapat meningkatkan ketrampilan menggunakan variasi metode mengajar, yaitu :

a. Belajar sendiri ( autodidact)

Banyak orang yang meningkatkan kualitas mengajarnya dengan belajar sendiri. Belajar sendiri memerlukan motivasi yang besar yang datang dari guru itu sendiri. Selain motivasi, tersedianya kondisi yang kondusif juga sangat penting membantu proses belajar pada seseorang. Salah satunya tersedianya perpustakaan yang memadai dan menyediakan buku-buku tentang mengajar yang baik. Dengan demikian guru dapat meningkatkan keterampilan mengajarnya dengan membaca sendiri kemudian menerapkannya dalam pembelajaran.

b. Studi lanjut ke jenjang yang lebih tinggi

Agar kemampuan mengajar seorang guru dapat lebih baik, maka belajar atau sekolah ke jenjang yang lebih tinggi dapat dilakukan. Hal ini dapat ditempuh melalui kuliah di perguruan tinggi yang memberikan pelayanan tentang pendidikan khususnya dalam mengajar.

c. Mengikuti penataran, seminar, diskusi-diskusi dan pelatihan untuk meningkatkan mutu pengajaran.

Dalam proses pembelajaran penguasaan terhadap bagaimana menggunakan media merupakan keterampilan lain yang juga diharuskan bagi seorang guru. Media merupakan kelengkapan belajar yang harus ada disekolah. Fungsinya berguna sebagai alat bantu pengajaran, peraga dan sumber belajar. Jika guru mampu menghadirkan pengajaran yang bervariasi menggunakan media tertentu maka dengan sendirinya akan memicu sekolah menyediakan berbagai fasilitas

\section{Paris Langkis}

Vol.2 Nomor 1, Agustus 2021 
yang mendukung bagi penggunaan pengajaran yang bervariasi. Atau setidaktidaknyan siswa secara kreatif menyediakan berbagai fasilitas yang memungkinkan ketika guru mengajar.

Selanjutnya memberikan motivasi memegang peranan penting dalam belajar. Seorang siswa tidak akan dapat belajar dengan baik dan tekun jika tidak ada motivasi didalam dirinya. Bahkan tanpa motivasi, seorang siswa tidak akan melakukan kegiatan belajar. Maka dari itu, guru harus selalu memberikan motivasi ini dan berusaha agar tetap tergejolak didalam diri setiap siswa selama pengajaran langsung. Dalam proses belajar mengajar dikelas, tidak semua siswa mempunyai motivasi yang sama terhadap sesuatu bahan.

\section{KESIMPULAN}

Dari uraian yang telah penulis kemukakan pada Bab-bab sebelumnya terkait Variasi Metode mengajar Guru dalam mengatasi kejenuhan siswa di Sekolah maka dapat diambil kesimpulan sebagai berikut:

Dalam menerapkan metode mengajar yang bervariasi, guru melakukannya dengan memberikan metode ceramah untuk menyampaikan materi dengan penjelasan yang lebih detail dan luas. Untuk menghindari kebosanan siswa karena hanya mendengarkan maka, diselingi dengan metode tanya jawab. Metode tanya jawab ini dilakukan untuk mengetahui kemampuan siswa dalam menerima pelajaran yang telah diberikan.

Dalam upaya menciptakan variasi metode mengajar untuk mengatasi kejenuhan siswa di Sekolah, ada beberapa kendala yang dihadapi guru yaitu guru lebih banyak menggunakan metode yang konvensional seperti ceramah dan tanya jawab. Ini juga yang menyebabkan kurangnya antusias siswa terhadapkegiatan belajar. Kurangnya kemampuan guru dalam mengembangkan dan menerapkan metode pembelajaran yang bervariasi, Kurangnya pengetahuan guru tentang siswasiswa yang dihadapi seperti tingkat kecerdasan siswa, bakat dan minatnya serta Guru kurang matang dalam mempersiapkan seperangkat pembelajarannya sehingga menghambat dalam pelaksanaan pembelajaran; serta kurangnya sarana yang tersedia dalam menunjang pembelajaran.

Upaya yang dapat dilakukan guru dalam membuat variasi metode mengajar untuk menyajikan materi pelajaran kepada siswa, adalah dengan mengkombinasikan beberapa metode pembelajaran misalnya kombinasi penggunaan metode ceramah tanya jawab dan tugas, metode ceramah diskusi dan tugas, metode ceramah demonstrasi dan eksperimen, dan lain sebagainya serta meningkatkan keterampilan mengajar khususnya keterampilan menggunakan metode yang bervariasi dalam pembelajaran yang baik dan terarah.

\section{Paris Langkis}

Vol.2 Nomor 1, Agustus 2021 


\section{DAFTAR PUSTAKA}

Anonim. Al-Quran dan Terjemah, Jakarta: Departemen Agama RI.

Akbar Zainudin, Man Jadda Wajada, Jakarta: Kompas Gramedia, 2010

Beni Ahmad Saebeni, Hendra Akhdiyat, Ilmu Pendidikan Islam, Bandung: Pustaka Setia, 2012.

Desmita, Psikolgi Perkembangan Peserta Didik, (Bandung: Remaja Rosdakarya, 2014.

Juliansyah Noor, Metodologi Penelitian, Jakarta: Kencana, 2011.

Mulyani Sumantri, Nana Syaodih, Perkembangan Peserta Didik, Jakarta: Universitas Terbuka 2010.

Muzayyin Arifin, Kapita Selekta Pendidikan Islam, Jakarta: Bumi Aksara2011.

Nasution, Didaktik Asas-asas Mengajar, Jakarta: Bumi Aksara, 2012

Oemar Hamalik, Proses Belajar Mengajar, Jakarta: Bumi Aksara, 2012.

Setyadi. Metode Penelitian Kuantitatif dan Kualitatif, Yogyakarta: Graha Ilmu, 2006 hal 219

Sugiyono, Haryanto, Belajar dan pembelajaran, Bandung: Remaja Rosdakarya, 2011.

Syamdani, 8 Keterampilan Dasar Mengajar, Jakarta: Teras, 2013.

Syaiful Bahri Djamarah dan Aswan Zain, Strategi Belajar Mengajar, Jakarta: Rineka Cipta, 2006.

Undang-undang Republik Indonesia No. 14 Tahun 2005 Tentang Guru EB sDosen.

Paris Langkis

Vol.2 Nomor 1, Agustus 2021 